\title{
The Development of Socio-Cultural Society in Orwell's 'Nineteen Eighty Four'
}

\author{
Dr. Udayan Mukherjee \\ Department of English, F. G. College, Patna (Magadh University) INDIA
}

\begin{abstract}
George Orwell's Nineteen Eighty Four reflects the paranoia that prevailed in Europe during the interregnum of the two World Wars of the twentieth century society. The two World Wars and the Great Depression cast a sense of shock, horror and disillusionment. The rise of Fascism and Nazism left the people terrified and confused. The existing political institutions could not cope with this situation. The novel also reveals the political views of the novelist. He was of the opinion that justice and freedom are the two important aspects of every issue, raised by the problems of society. He divided the world into three great powers-Oceania, Eurasia and East Asia. According to him, these powers are always at war with one another.
\end{abstract}

Keywords: Airstrip One, Communism, Fascism, Marxism, Secondhand Shop, Socialism.

\section{Introduction}

George Orwell is one of the leading novelists of modern age. His novels express a powerful satire on the political and social hypocrisies. By the quality of his writing, he has achieved international fame and recognition. He wished to identify himself with the poverty-stricken people and to equate his sufferings with theirs. Orwell established a relationship between literature and politics. All his novels are a fine expression of his views on the subject of politics. Burmese Days, Animal Farm and Nineteen Eighty Four declare that he was a political thinker. Undoubtedly he wrote fiction of satire on the one hand and he penned his autobiography on the other. But he joined all these forms successfully and he did not give up the main subject of his writings.

The lack of emotions in his novels reveals that he was not a poetic writer. He did not use the symbols in that way in which Dickens and D. H. Lawrence were interested. Dickens used his symbolism in poetic manner while Orwell presented in a mechanical way. The symbols in the episodes of Gordon Comstock's Aspidistra in Keep the Aspidistra Flying, George Bowline's Flashing in Coming up for Air, the animals in Animal Farm and the secondhand shop in Nineteen Eighty Four, are mechanical. Therefore, his novels show that he has written his novels in prose style. Like the novels of Hardy or those of Dickens, his novels do not sound the music of poetry.

The last novel, Nineteen Eighty Four also reveals the political views of the novelist. He was of the opinion that justice and freedom are the two important aspects of every issue, raised by the problems of society. He divided the world into three great powers-Oceania, Eurasia and East Asia. According to him, these powers are always at war with one another. Dr. S. N. Subramanian, remarks, "The naturalist phase from The Way of All Flesh onwards, even to Orwell's Nineteen Eighty Four has thrust on us a great social function even than on the play." 1

George Orwell's Nineteen Eighty Four reflects the paranoia that prevailed in Europe during the interregnum of the two World Wars of the twentieth society. The two World Wars and the Great Depression cast a sense of shock, horror and disillusionment. The rise of Fascism and Nazism left the people terrified and confused. The existing political institutions could not cope with this situation. According to Satyabrata Das, "...with the prevailing social and economic chaos and in the face of the menacing rise of Fascism, it was Marxism and Socialism that emerged as some benign and promising God." ${ }^{2}$ During the 30s there were fierce ideological conflicts and the Spanish Civil War provided the 'first violent ...test of usefulness of Marxism as a means of ordering experience. During the Spanish Civil War the limitation of Soviet Russia was exposed by the Republicans and writers like George Orwell realized that 'the much promised God failed to keep His words. George Orwell's Nineteen Eighty Four is a political dystopia. It presents a futuristic society which is governed by a Party where people are controlled and conditioned to accept the principles of the Party without any dissent. Harold L. Berger opines that the prominent dystopian features of this novel include the following:

"The dictatorship of the Party whose object is power, the execution or brainwashing of dissidents, the divorce from values and memory of the past, the destruction of the capacity to think, through the perversion of language and the rejection of empirical evidence, the installation of the Party as the sole judge and origin of 
truth, the denigration of self-esteem; and the hostility to the joy of personal relationships and the appetite for joy itself, the maintenance of cultural stasis."

The projected world of Nineteen Eighty Four is a technically advanced society. We find tile screens, pneumatic tubes, speak writs, memory holes in this society. But these technical devices are not used to improve the standard of living of all the people. While the Inner Party members enjoy all comforts, life is made difficult for Outer Party members. George Orwell, for the representation of society in Nineteen Eighty Four, took as his model, the controlled and military society from Soviet Communism. It also points out the conflict between Stalin and Trotsky (Big Brother and observes Goldstein). The ideology of Airstrip One (London) is English Socialism. Raymond William's that when the book became a success in the United States Orwell had to issue a denial letter that this is not related to the postwar Labour Party. He wrote, "My recent novel is not intended as an attack on Socialism or on the British Labor Party ...but as a show-up of the perversions to which a centralized economy is liable and which have already been partly realized in Communism and Fascism." 4

In a press release made on 15 June 1949 Orwell affirmed that the world of Nineteen Eighty Four could happen because this is only a parody of the contemporary political, social economic situations. He assumes that if a society as we find in Nineteen Eighty Four comes into being there will be several super states. These super states will be in opposition to each other. Two of the principal super states will obviously be the Anglo-American World and Eurasia. If these two great blocks lineup as mortal enemies it is obvious that the Anglo-Americans will not take the name of their opponents and will not dramatis themselves on the scene of history as Communists. Thus they will have to find a new name for themselves. The name suggested in Nineteen Eighty Four is of course Ingsoc. ${ }^{5}$

As the title indicates, the story is set in 1984 in Airstrip One (England) which is a part of Oceania. The country is ruled by the Party which is led by Big Brother. The population of the country is divided into three groups - Inner Party, Outer Party and Paroles. The Party used indoctrination, propaganda and fear to establish order and conformity. The protagonist of the novel is Winston Smith, a member of the Outer Party, working in the Records Department of the Ministry' of Truth, rewriting and altering records, such as newspaperarticles, of the past. But Winston develops critical thoughts against the ruling. The Records Department in Ministry of Truth changes history when something does not seem right, or when a person has a thought against the ideals of the Party. It is done to make the people believe that the Party is always right. Past is constantly altered to go along with the Parry's standards. The Ministry of Peace ensures that people believe that there was a war going on. Its own city Oceania is bombed by the Party just to scare the people. The fear of people about the ongoing war will prevent them from paying any attention to other happenings in the country. The Ministry of Love is concerned with law and order. It makes sure that people do not even think against the ideals of the Party. If they do so they will be caught by the Thought Police and later conditioned to adopt themselves to the policies of the Party. The Ministry of Plenty is responsible for the economic affairs of the country. It makes sure that all food items are supplied to people. But it makes people believe that there is plenty of production and equal distribution of produce. In reality, only the members of the Inner Party enjoy ail privileges while the other sections of the society are made to toil. Contrary to what these ministries should do to govern the nation, they are effectively used by the Party to propagate their ideas and condition people to adopt themselves to the principles of the Party.

The citizens are constantly monitored by the Party. At the beginning of the novel we find Winston Smith in his dingy apartment trying to write in the diary furtively which was bought by him without the knowledge of the Party. He finds the face of Big Brother on the wall in the form of a poster and it is designed in such a way that people are always apprehensive of being watched by it. When Winston took a twenty-five cent piece out of his pocket he finds the slogans of the Party "War is Peace; Freedom is Slavery; Ignorance is Strength" being inscribed and on the other face of the coin he finds of the head of Big Brother. "Even from the coin the eyes pursued you. On coins, on stamps, on the covers of books, on banners, on posters, and on the wrappings of a cigarette packet everywhere. Always the eyes watching you and the voice enveloping you. Asleep or awake, working or eating, indoors or out of doors, in the bath or in bed- no escape. Nothing was your own except the few cubic centimeters inside your skull. "6

Even children are trained to monitor the movements of their parents and neighbors. Clubs such as Spies and Youth Leagues are meant for children and young people who are 'systematically turned into ungovernable savages'. Yet this type of training did not produce in them any tendency to rebel against the discipline of the party. "On the contrary, they adored thigh Party and everything connected with it. The songs, the processions, the banners, the hiking, the drilling with dummy rifles, the yelling of slogans, the worship of Big Brother -it was all the sort of glorious game to them. All the ferocity was turned outwards, against the enemies of the State, against foreigners, traitors, saboteurs, thought-criminals." ${ }^{7}$ In Russia during and after Revolution people were not sure whether a person is their friend or foe. Even though they used to call others 'comrades' as we find in Nineteen Eighty Four by Orwell, real camaraderie was missing. A new language called 'Newspeak' was created by the government to minimize the use of words and thereby limiting 
the process of thought itself. Newspeak, the official language of Oceania, was created with the intention of meeting the ideological needs of Ingsoc or English Socialism. Even though in the year 1984 it was not used by all to be the sole means of communication, either in speech or writing, newspaper articles were written in it with the help of a specialist. Newspeak is used not only to provide mediums of expression but also 'to make all other modes of thought impossible. ${ }^{8}$ Chapter five, Syme who works in the Research Department talks to Winston that the eleventh edition of Newspeak Dictionary is getting into its final shape. "I dare say that our chief job is inventing new words. But not a bit of it! We are destroying word - scores of them, hundreds of them, everyday. We're cutting the language down to the bone." ${ }^{9}$ Words are reduced to minimum in the futuristic world of Orwell's. For example, adjectives and nouns are reduced so that a word contains its opposite in itself. A word like 'good' will not give' bad' as antonym. 'Ungood' will be considered an exact opposite. Similarly expressions like 'splendid' 'excellent' will lose their significance. Instead 'plus good' or 'double plus good' will convey the meaning. Syme, an intelligent person unlike many other citizens of Oceania, understands the purpose of reducing words, "...the whole aim of Newspeak is to narrow the range of thought. In the end we shall make thought crime literally impossible. Every concept ... will be expressed by exactly one word...all its subsidiary meanings rubbed out and forgotten. The Revolution will be complete when the language is perfect. Newspeak is Ingsoc and Ingsoc is Newspeak." ${ }^{10}$ Language is thus used effectively in Orwell's futuristic world to make people accept the designs of the government. As we find in Huxley's Brave New World. Language, rhyme and meter are used by dictators to condition their citizens. A few cubicle away from that of Winston's we find a man named Ample forth juggling with rhymes and meters to produce gargle versions of poems which 'had become ideologically offensive, but which for one reason or another are to be retained in the anthologies'. ${ }^{11}$ In Huxley's Brave New World, Helmholtz Watson is entrusted with this job. Though they share the same job of modifying and creating new poems for emotional engineering they have different intellectual level. Language assumes meaning only in a social context. It is a powerful tool for supporting the dominant group within a society. According to Scott A. Bounding, Language is a tool shaping the very way in which individuals construe reality and "it is biased infamous of the dominant group". ${ }^{12}$

The Orwell's novel, Nineteen Eighty Four, the state insists that passion, desire and love must be expressed only towards Big Brother. The citizens are conditioned to hate others. In Nineteen Eighty Four, we also see how the fear of war is exploited by Big Brother to manage social solidarity. The purpose of Big Brother is to instill fear and paranoia in society so that the only way of security is to believe that the government is always taking the right measures to protect its citizens. It is universally true of any modern governance; bureaucratization is perpetuated by the threat of social upheaval, revolution or war. Such excited state of affairs projected by the ruling elite, succeeds in snuffing / silencing all political debates on the issues on hand.

History is constantly rewritten to suit the current goals of the Party. Only the destruction of human memory will make it possible. Hence the Ministry of Truth modifies history perpetually to the tune of the ideals of the Party. Winston could remember the fight at the time of Revolution when an atom bomb was dropped on Colchester. But the history of the fighting could not be traced out. In the year 1984 Oceania is at war with Eurasia and East Asia it is alliance. 'In no public or private utterance was it ever admitted that the three powers had at any time been grouped along different lines.' (George Orwell 30) Though Winston knows that four years ago Oceania was at war with East-Asia and in alliance with Eurasia he could tell it to any one and not can it be proved as the records are rewritten to create an impression that Oceania is at war with Eurasia, as it is eternal enemy. 'The enemy of the moment always represented absolute evil, and it followed that any past or future agreement with him was impossible.'(George Orwell 31)The Party history books claim that it invented aeroplanes. Winston had seen aeroplanes long before the Party formed government. But it cannot be proved because there is no evidence. Even people cannot rely on their memory. Winston struggles to remember his childhood."It was extraordinarily difficult beyond the late fifties everything faded. When there were no external records that you could refer to, even the outline of your life lost its sharpness." (George Orwell 29)The economic condition of 1984 resembles that of Russia. To, Winston Smith, readjusting Ministry of Plenty's figures is not even forgery. Rather it appears like substituting one piece of nonsense for another because most of the figures mentioned do not have any connection with the real world. For example, the Ministry of Plenty's forecast had estimated the output of boots for the quarter at 145million pairs. The actual output was...sixty-two millions. Very likely, no boots had been produced at all. Likelier still, nobody knew how many had been produced, much less cared. All one knew was that every quarter produced astronomical numbers of boots were produced on paper, while perhaps half the population of Oceania went barefoot. And so it was with every class of recorded fact, great or small. (George Orwell 36)People who showed intelligence incurred the wrath of the Party and disappeared suddenly. 'Thought criminals' were arrested and were either condemned publicly or released after cleansing but were killed after a few years. The fourth message Winston received that morning required him to do some serious work because what was written in Newspeak can be rendered in Old speak as: "The reporting of Big Brother's Order for the Day, in 
The Times of December 3rd 1883 is extremely unsatisfactory and makes references to non -existent persons. Rewrite it in full and submit your draft to higher authority before filing." (George Orwell 39) Praising the work of an organization known as FFCC, Big Brother awarded the order of Conspicuous Merit, Second Class to a person known as Withers. Soon FFCC was dissolved for no obvious reason. Withers and his associated might fall out of the favor of the Party. But it was not reported in the Press or on the tele- screen. It was unusual for political offenders to be tried publicly and publicly denounced. Traitors and criminals were made to confess their crimes publicly and afterwards they were executed. It is a show-piece that occurred rarely, once a couple of years. But, more commonly, 'people who had incurred the displeasure of the Party simply disappeared and were never heard of again. One never bad the smallest ' clue as to what had happened to them.' (George Orwell 39)

The award given to Withers should be rewritten so that the very existence of a human called Withers will never have any proof. Winston had to rewrite the speech of the Big Brother and submit it to authorities for editing. Winston knew that he would not be the only man working on it. He thought that Tillotson, a man who sat next to him as well as a few others would all be producing different versions, which would finally be edited, and the best piece would be selected. Winston was ordered to rewrite the speech of the Big Brother without mentioning FFCC and Withers. So he invented a name Captain Ogilvy who sacrificed his life fighting for the nation. Even though he did not exist in real life, Big Brothers tribute to Ogilvy and some faked photographs would make others believe that he was a real character.

The primary job of Records Department was not reconstruct the past but to supply the citizens of Oceania with' newspapers, films, textbooks, telescreen programmers, plays, novels with every conceivable kind of information, instruction, or entertainment, from a statue to a slogan, from a lyric poem to a biological treatise, and from a child's spelling-book to a Newspeak dictionary' (George Orwell 38). The Ministry of Truth not only supplies the multifarious needs of the party, but also 'repeats the whole operation at a lower level for the benefit of the proletariat'(George Orwell 38). It produces cheap entertainment material for proletariats. Even a sub-section called "Pornsec" in Newspeak produced pornography which nobody other than who work on it can see. They would then be sent out in sealed covers. A Black in a recent article in the Guardian illustrates the same trend followed by modern governments. Preparing text books assumes greater importance nowadays as the children understand history only from what they study. Any attempt to change history will lead to 'conditioning' we find in the futuristic societies of Orwell and Huxley. The order of the Israel's Educational Ministry to remove the word 'nakba' - Arabic for the 'catastrophe' - in the text book for young Arab children is considered to be a setback in historical narrative by Arab people. Palestinians have always maintained that the 1948refugees were the victims of Israel's 'ethnic cleansing' while Israelites opines that it makes the creation of their country and the use of the word 'nakba' is tantamount to spreading propaganda against Israel. History should be written with all its glory and gore and any effort to rewrite to make it feasible for the present will result in biased opinions. ${ }^{13}$

The role of Winston and Julia get expunged from the records of government in the novel, Nineteen Eighty Four. This can be read as an allegory of Stalin's efforts to obliterate the contribution of Trotsky in the Russian Revolution. The process of rewriting is apparent in the Russian encyclopedias. Trotsky was portrayed as a hero in the first edition of the Soviet Encyclopedia. But he was presented as a traitor in the second edition and a non-person in the third. History is something created by rulers. In the words of Bernard Crick, "false history can only make the past irretrievable." (Bernard Crick 80) In totalitarian states the governments ensure that all evidences contrary to the ideology of the party are destroyed, and the records are falsified / forged. They also ensure that the falsification does not get exposed.

Even if a person knew the truth he could not prove it. Winston's experience is widely considered an artistic recreation of Orwell portraying the coercive methods of the Stalin and Nazis. Samuel Hynes argues that "Orwell's imagination was one that depended upon documentation and the sense of recorded fact ...Big Brother looks like Stalin, Goldstein is a Trotsky-like dissenting intellectual, and the purges, trials, and tortures resemble those that decimated the Russian party during the thirties." 14

\section{Conclusion}

This novel depicts a society that resembles a concentration camp. The citizens are conditioned, monitored and made to live in eternal fear without protest. They merely exist and do not protest against totalitarian rule. The first proposed title for this novel was "The Last Man in Europe". This title itself suggests a bleak future where people are deprived to live a decent life and lose social identity. In Nineteen Eighty Four the citizens are monitored and conditioned through coercive methods. They live under a sense of perennial fear so that they cannot think or question the motives and principles of the Party. In our own society we are conditioned by discursive methods so that we pay scant attention to important things. Rather we are conditioned to pay attention to trifles. The motive of the government is to retain power by making people not to think independently. The core idea of Communism as envisioned by Marx is to establish a classless society and 
equal distribution of production. But after tasting power, communist leaders like Stalin paid scant respect to this fundamental tenet and concentrated on building power equations. Orwell ridiculed this revisionist stand of Stalin in The Animal Farm, in the rewriting of the first commandment from "All Animals are Equal" to "All Animals are Equal, but some are more equal than others." ${ }^{15}$ It was welcomed by the right wing as a condemnation of communism and the authoritarian tendencies of socialism, but, in fact, Nineteen Eighty-Four condemned totalitarianism of every kind and, just as strongly, the sterility of modern life, a sterility which Orwell believed until his death in 1950 could be best countered by socialism.

Orwell's Nineteen Eighty Four reveals that the novel is well grounded in the socio - cultural of the middling years of the two world wars. During the time governments went on asperse for restricting individual freedom and insisting on conformity to its policies through the twin instruments of power, namely coercion and discursive practice, by making the media sub serve their ideology and thus perpetuate hegemony, by interpellation. The novel is relevant not only in the contexts of its production, but its account of state control holds true even in the context of reception. Nineteen Eighty Four is not pageantry or dystopia but a valid critique of power equations of modern society.

\section{References}

[1]. Dr. S. N. Subramanian, Movements in Modern English Novel. (Atlantic Publishers and Distributors, New Delhi. 1996). P: 69.

[2]. Das, Satyabrata, George Orwell: The Man Who Saw Tomorrow (Atlantic Publishers and Distributors, New Delhi. 1996). P: 42.

[3]. Berger, L. Harold, Science Fiction and the New Dark Age. (Ohio: Bowling Green University of Popular Press, 1976 ).P:88.

[4]. Ed. Orwell, Sonia and Ian Angust, Collected Essays, Journalism and Letters of George Orwell, 1968. (As quoted by Raymond Williams in Orwell edited by Frank Kermode, 1971. Fontana Modern Masters Fontana / Collins: Great Britain). P: 502.

[5]. Ed. Crick, Bernard, George Orwell: Nineteen Eighty Four (with a critical introduction and annotations by Bernard Crick). Oxford: Clarendon Press 1984. P: 153.

[6]. Orwell, George, Nineteen Eighty Four. (Penguin Books). P: 25.

[7]. Ibid, P: 23.

[8]. lbid, P: 241

[9]. Ibid, P: 44

[10]. Ibid.P:45.

[11]. lbid, P: 37

[12]. Boulding, A Scott, "The Road to Postmodernism through Dystopia", (the road to postmodernismthough dystopia, Jason, 1996).

[13]. The Hindu, Friday July 24, 2009. "Changing the Historical Narrative". P: 9

[14]. Ed. Church, Margaret and William T. Stafford, Modern Fiction Studies of English, Volume: 21 Numbers: 1. "Orwell and AntiSemitism: Toward 1984". (Melvyn Crew. West Lafayette. Indiana 47907: Purdue University). P: 84.

[15]. Orwell, George, Animal Farm. (Delhi: A.I.T.B.S. Publishers India, 2008). 